\title{
KANDUNGAN ZAT KIMIA ANORGANIK PADA BEBERAPA PROSES FILTRASI AIR MINUM KEMASAN DAN ISI ULANG MENGGUNAKAN ONE-WAY MANOVA
}

\author{
Heruna Tanty \\ Jurusan Matematika dan Statistik, Fakultas Sains dan Teknologi, Universitas Bina Nusantara \\ Jln. K.H. Syahdan No. 9, Palmerah, Jakarta Barat 11480 \\ heruna@binus.ac.id
}

\begin{abstract}
Analysis of chemical substances in some processes an-organic bottled water and drinking water recharge has been done using One Way Manova. Samples originated from springs Ciburial Bogor taken in May 2009 at 10 depots refill drinking water process (AMDIU) Around Syahdan and Anggrek Campus of Bina Nusantara University. Reserve osmosis filtration processes and filtration Hollow Fiber and testing of heavy metal contents of five $\mathrm{CN}, \mathrm{Pb}, \mathrm{Mn}, \mathrm{Cr}$, and $\mathrm{Cd}$ in the company carried out the bottled water (bottled water) PT Buana Cikarang Tirta Abadi. Test results and analysis show that the processed water filtration contains $\mathrm{CN}, \mathrm{Pb}, \mathrm{Mn}, \mathrm{Cr}$, and $\mathrm{Cd}$ was lower than that of water filtration was not processed. And drinking water processed by filtration Reserve Osmosis, contains $C N, \mathrm{~Pb}, \mathrm{Mn}, \mathrm{Cr}$, and Cd was lower than that processed by Hollow Fiber Filtration and Granular Activated Charcoal.
\end{abstract}

Keywords: inorganic chemical material, bottled drinking water, one way manova

\begin{abstract}
ABSTRAK
Analisis kandungan zat kimia anorganic pada beberapa proses air minum kemasan dan air minum isi ulang telah dilakukan dengan menggunakan One Way Manova. Sampel yang berasal dari mata air Ciburial Bogor diambil pada bulan Mei 2009 di 10 depot proses air minum isi ulang (AMDIU) sekitar Kampus Syahdan dan Anggrek Universtas Bina Nusantara. Proses filtrasi Reserve Osmosis dan filtrasi Hollow Fiber serta pengujian kandungan lima logam berat $C N, P b, M n, C r$ dan Cd dilakukan di perusahaan air kemasan (AMDK) PT Buana Tirta Abadi Cikarang. Hasil pengujian dan analisis menunjukan bahwa air yang diproses filtasi memiliki kandungan $\mathrm{CN}, \mathrm{Pb}, \mathrm{Mn}, \mathrm{Cr}$ dan $\mathrm{Cd}$ lebih rendah dari air yang tidak diproses filtrasi. Dan air minum yang diproses dengan filtrasi Reserve Osmosis, memiliki kandungan $\mathrm{CN}, \mathrm{Pb}, \mathrm{Mn}, \mathrm{Cr}$, dan $\mathrm{Cd}$ lebih rendah dibanding yang diproses dengan filtrasi Hollow Fiber dan Granular Activated Charcoal.
\end{abstract}

Kata kunci: zat kimia anorganik, air minum dalam kemasan, one way manova 


\section{PENDAHULUAN}

Air merupakan kebutuhan pokok bagi manusia, hampir dua per tiga bagian massa tubuh manusia berisi cairan, oleh karena itu setiap hari dianjurkan untuk minum air sebanyak delapan gelas atau sekurang-kurangnya dua setengah liter, dan sebaiknya mengkonsumsi air putih, karena air putih memiliki daya larut yang tinggi sehingga metabolisme tubuh berjalan dengan baik. Hal ini sangat penting apalagi hidup di iklim tropis di mana akan lebih banyak cairan tubuh yang keluar sehingga akibatnya jika tubuh kurang minum maka terjadi dehidrasi dan dapat merusak sel saraf tubuh; Air juga membantu oksigen bersikulasi keseluruh sel tubuh. Terbukti bahwa oksigen dan air adalah sebuah keterkaitan yang erat sekali. Bisa dibayangkan jika tubuh manusia kekurangan air.

Meskipun air begitu vital, masyarakat jarang sekali mengawasi mutu air yang dikonsumsi dan sering kali menganggap ringan tentang hal ini. Air minum yang sehat harus memenuhi persyaratan fisik, kimia, maupun bakteriologis. Untuk mendapatkan kualitas air yang baik maka air perlu diproses terlebih dahulu sebelum dikonsumsi. Karena pasokkan air dengan jumlah dan kualitas yang tidak mencukupi, pengolahan air minum dalam kemasan (AMDK) dewasa ini meningkat tajam. Hal ini mendorong pertumbuhan industri AMDK di kota-kota besar di Indonesia khususnya Jakarta. Selain itu, industri air minum depot isi ulang (AMDIU) juga tumbuh pesat dan telah menjadi salah satu alternatif bisnis skala usaha kecil dan menengah. Ada pula produk untuk pemrosesan air minum yamg saat ini dijual dipasaran, masyarakat dapat membeli kemudian dipasang pada saluran air di rumah. Biasanya proses filterisasi ini menggunakan proses filterisasi yang disebut fiter Hollow Fiber. Untuk perusahaan AMDK umumnya menggunakan proses filterisasi yang disebut proses filter Reserve Osmosis (RO). Sedangkan untuk perusahaan AMDIU umumnya menggunakan proses filterisasi yang disebut sebagai proses filter Granular Activated Charcoal (GAC). Banyak analisis tentang kualitas air minum yang dikatakan telah memenuhi standar kesehatan atau standar kelayakkan konsumsi air. Asalkan air tersebut tidak bau, tidak berwarna, tidak mengandung bakteri maupun virus, atau sudah dimasak, maka air tersebut sudah dinyatakan layak untuk dikonsumsi. Padahal ada zat-zat kimia tertentu dalam air yang bersifat toksik bagi tubuh, yaitu zat kimia anorganik seperti logam-logam berat yang bila terus menerus dikonsumsi akan menimbulkan endapan dalam tubuh dan dapat menimbulkan berbagai jenis penyakit.

Dalam penelitian ini, rumusan masalahnya adalah sebagai berikut. Pertama, apakah benar ada perbedaan antara air sebelum diproses dengan air yang melalui proses filterisasi dari segi kandungan zat kimia anorganik $\mathrm{CN}, \mathrm{Pb}, \mathrm{Mn}, \mathrm{Cr}$, dan $\mathrm{Cd}$. Kedua, apakah ada perbedaan antara air yang diproses dengan cara yang berbeda dari segi kandungan zat kimia anorganik yang terkandung dalam air tersebut. Ketiga, dari beberapa proses filterisasi pada air minum, jenis pemrosesan manakah yang menghasilkan air minum yang paling baik untuk dikonsumsi.

Penelitian ini dilkukan dengan tujuan sebagai berikut. Pertama, meneliti kandungan logam berat $\mathrm{CN}, \mathrm{Pb}, \mathrm{Mn}, \mathrm{Cr}$, dan $\mathrm{Cd}$ yang terdapat dalam air minum isi ulang dan beberapa macam proses filterisasi. Kedua, mencari apakah ada perbedaan kandungan zat kimia anorganiknya antara air yang diproses dengan berbagai proses filterisasi terhadap air yang tidak melalui proses filterisasi. Ketiga, dari berbagai macam proses filterisasi pada air minum akan dicari proses filterisasi manakah yang sama atau berbeda dari kandungan ke lima zat kimia anorganiknya. Keempat, dari beberapa proses filterisasi pada air minum, jenis filterisasi manakah yang menghasilkan air minum yang paling baik untuk dikonsumsi.

Definisi air adalah substansi kimia dengan rumus kimia $\mathrm{H}_{2} \mathrm{O}$. Satu molekul air tersusun atas dua atom hidrogen yang berikatan dengan satu atom oksigen. Air merupakan pelarut universal sehingga dalam air dapat terlarut berbagai zat padat (misalnya: garam garam mineral), unsur cair (asam, basa) dan unsur gas (misalnya: hidrogen, oksigen, karbondioksida dll). Dan definisi air minum adalah suatu cairan yang dapat diminum (Brown 2001: 20). 
Definisi kadar zat kimia adalah jumlah massa zat kimia yang terlarut dalam jumlah volume air. Kadar zat kimia dalam air menggunakan satuan mg/liter atau ppm. (Brown 2001: 34).

Air mengandung $75.3 \%$ zat kimia anorganik dan $24,7 \%$ zat kimia organik Zat kimia organic misalnya magnesium, kalsium, nitrat, phosfat dll. Sedangkan zat kimia anorganik, yaitu alumunium, barium, klorium, mangan, tembaga, fluorida, timbal, kromium, kadmium, dan lain lain. Zat kimia organik sangat dibutuhkan oleh tubuh, karena itu dalam pengolahan air diusahakan zat-zat kimia ini tidak dihilangkan, sedangkan zat kimia anorganik tidak dibutuhkan oleh tubuh sama sekali dan bahkan berbahaya bagi tubuh. Oleh karena itu keberadaannya dalam air minum harus dihilingkan atau ditekan sekecil mungkin jumlahnya. (Brown, 2001: 203).

Kadmium (Cd) merupakan logam yang hingga saat ini belum diketahui dengan jelas peranannya bagi tumbuhan dan makhluk hidup lain. Kadmium bersifat tidak larut dalam air, memiliki ukuran yang sangat kecil \pm 0.65 micron dan bersifat toksik. Garam-garam kadmium adalah hasil reaksi dari klorida $\left(\mathrm{Cl}^{-}\right)$, nitrat $\left(\mathrm{NO}_{3}^{-}\right)$, dan sulfat $\left(\mathrm{SO}_{4}{ }^{2-}\right)$. Pada $\mathrm{pH}$ dan kesadahan yang tinggi kadmium mengalami pengendapan. Menurut WHO, kadar kadmium maksimum pada air yang diperuntukkan bagi air minum adalah $0.005 \mathrm{mg} /$ liter (Moore, 1991).

Dampak akumulasi cadmium di dalam tubuh, yaitu (Eckenfelder, 1989: 44) gangguan fungsi ginjal, kanker paru-paru, meningkatkan tekanan darah, kemandulan pada pria dewasa, dan pengeroposan tulang. Kromium $(\mathrm{Cr})$ merupakan logam yang larut dalam air dan bereaksi dengan oksigen. Kadar kromium yang diperkenankan pada air minum adalah $0.05 \mathrm{mg} /$ liter (Brown, 2001: 203). Dampak akumulasi kromium di dalam tubuh manusia menurut Eckenfelder (1989: 46), yaitu kanker usus dan gangguan pencernaan atau peradangan pencernaan.

Mangan (Mn) merupakan logam yang memiliki karakteristik kimia serupa dengan bes Kadar mangan yang diperkenankan pada air minum adalah 0.1 mg/liter (Brown, 2001: 210). Dampak akumulasi mangan di dalam tubuh manusia menurut Eckenfelder (1989: 50) adalah pertumbuhan tubuh terhambat, penyumbatan pada sistem saraf, dan proses reproduksi terganggu.

Menurut WHO, kadar maksimum sianida $(\mathrm{CN})$ yang diperkenankan pada air minum adalah 0,1 mg/liter (Brown, 2001: 241). Dampak akumulasi sianida di dalam tubuh manusia menurut Eckenfelder (1989: 53), yaitu menghambat pertukaran oksigen dalam tubuh, mengganggu fungsi hati, dan menyebabkan pengeroposan tulang atau osteoporosis.

Timbal $(\mathrm{Pb})$ tidak mudah larut dalam air, menurut WHO, kadar maksimum timbal yang diperkenankan pada air minum adalah 0,05 mg/liter (Brown, 2001: 257).

Dampak akumulasi timbal di dalam tubuh manusia menurut Eckenfelder (1989: 58), yaitu gangguan pada otak dan terjadi gagal ginjal serta kemunduran mental pada anak yang berada dalam masa pertumbuhan. Proses Air Minum Depot Isi Ulang (AMDIU) menggunakan filtrasi Granular Activated Charcoal (GAC) dengan tahapan seperti tertera pada Gambar 1. 


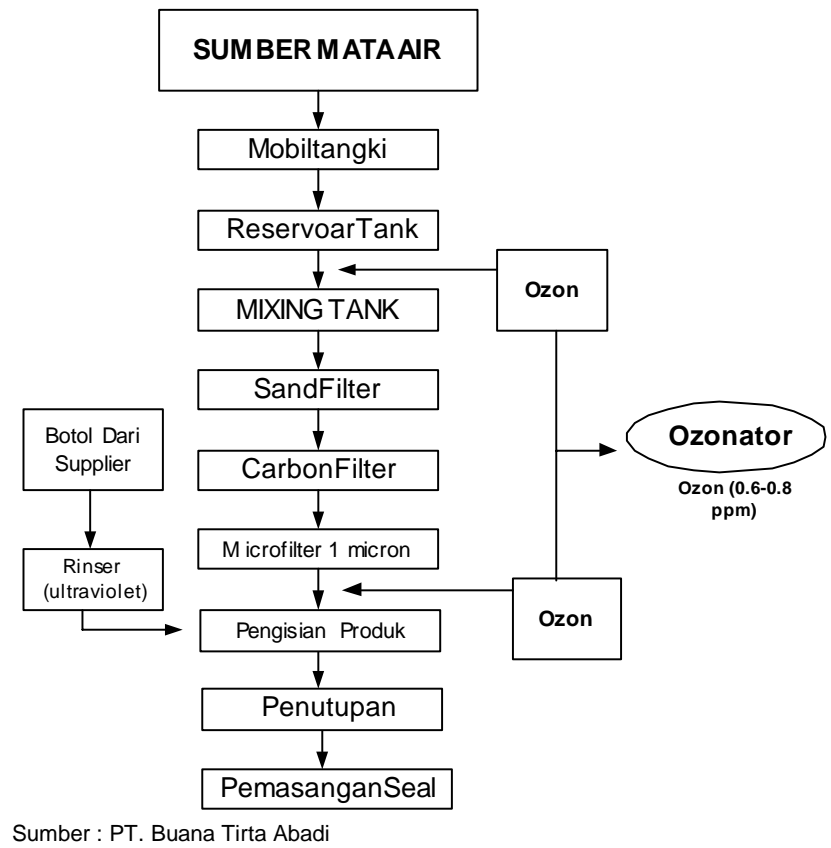

Gambar 1 Proses Filter Granular Activated Charcoal (GAC)

Selain proses Filter Reserve Osmosis, untuk air minum dalam kemasan biasanya menggunakan proses Filter Hollow Fiber yang terdiri dari beberapa langkah (Gambar 2).

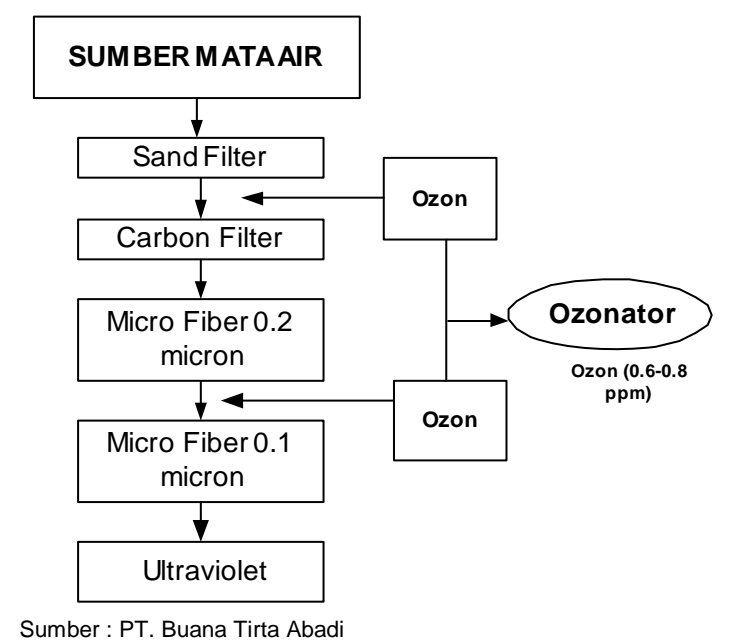

Gambar 2 Proses Filter Hollow Fiber

Proses Air Minum dalam Kemasan (AMDK) dilakukan dengan proses filter Reserve Osmosis (RO) dengan tahapan sepeti pada Gambar 3. 


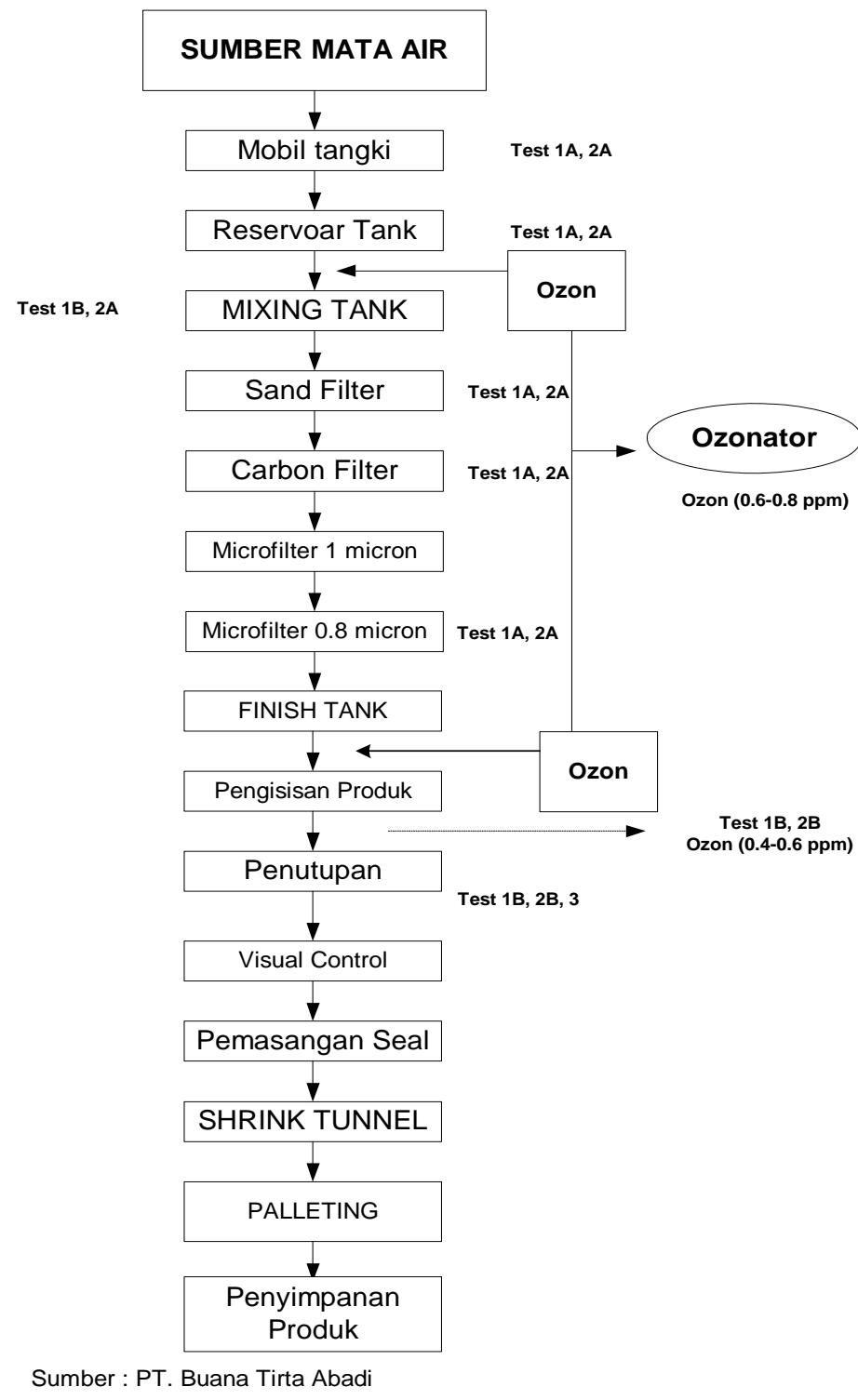

Gambar 3 Proses Filter Reserve Osmosis (RO)

MANOVA menurut Hair (1998: 327) adalah teknik statistikal yang digunakan untuk membandingkan rata-rata group yang memiliki variabel tak bebas lebih dari satu. Model analisis ragam multivariat satu arah (ONE-WAY MANOVA) dapat dilihat pada persamaan sebagai berikut.

$$
\begin{aligned}
& x_{i j k}=\mu_{k}+\tau_{i k}+\varepsilon_{i j k} \\
& i=1,2, \ldots t \\
& j=1,2, \ldots n_{i} \\
& k=1,2, \ldots p
\end{aligned}
$$

Keterangan : $x_{i j k}=$ nilai pengamatan dari respon ke-k, ulangan ke- $\mathrm{j}$ yang memperoleh perlakuan ke-i.

$\mathrm{t} \quad=$ banyaknya perlakuan.

$\mathrm{p} \quad=$ banyaknya respon. 
$n_{i} \quad=$ banyaknya ulangan yang memperoleh perlakuan ke-i

$\mu_{\mathrm{k}} \quad=$ nilai rata-rata yang sesungguhnya dari respon ke-k

$\tau_{i k} \quad=$ pengaruh dari perlakuan ke-i terhadap respon ke-k

$\varepsilon_{i j k} \quad=$ pengaruh galat (error) yang muncul pada pengukuran $x_{i j k}$, artinya yang timbul dalam ulangan ke-j yang memperoleh perlakuan ke-i.

Prosedur untuk analisis ragam multivariat satu arah (ONE-WAY MANOVA) pada Tabel 1.

Tabel 1 One-Way Manova

\begin{tabular}{lll}
\hline Sumber Keragaman & $\begin{array}{c}\text { Matriks Jumlah Kuadrat } \\
\text { dan Hasil Kali Silang }\end{array}$ & Derajat bebas \\
\hline Perlakuan & $\mathbf{J K}_{\text {Perlakuan }}$ & $\mathrm{t}-1$ \\
Galat & $\mathbf{J K}_{\text {Galat }}$ & $\sum_{l=1}^{t} n_{l}-t$ \\
\hline Total & $\mathbf{J K}_{\text {Total }}$ & $\sum_{l=1}^{t} n_{l}-1$ \\
\hline
\end{tabular}

$$
\begin{aligned}
\mathbf{J K}_{\text {Perlakuan }} & =\sum_{l=1}^{t} n_{l}\left(\bar{x}_{l}-\bar{x}\right)\left(\bar{x}_{l}-\bar{x}\right)^{\prime} \\
\mathbf{J K}_{\text {Galat }} & =\sum_{l=1}^{t} \sum_{j=1}^{n_{l}}\left(x_{l j}-\bar{x}_{l}\right)\left(x_{l j}-\bar{x}_{l}\right)^{\prime} \\
\mathbf{J K}_{\text {Total }} & =\mathbf{J K}_{\text {Perlakuan }}+\mathbf{J K}_{\text {Galat }} \\
& =\sum_{l=1}^{t} \sum_{j=1}^{n_{l}}\left(x_{l j}-\bar{x}\right)\left(x_{l j}-\bar{x}\right)^{\prime}
\end{aligned}
$$

Dalam percobaan menggunakan ONE-WAY MANOVA, maka pengujian hipotesis yang diuji adalah sebagai berikut.

$H_{0}$ : Tidak ada perbedaan antar rata-rata perlakuan.

$H_{1}$ : Paling sedikit ada satu nilai rata-rata perlakuan yang berbeda dengan nilai rata-rata perlakuan lainnya.

Untuk menguji hipotesis, maka dapat menggunakan uji Lambda-Wilks ( $\Lambda$-Wilks) menggunakan tabel distribusi $\mathrm{U}$, sebagai berikut :

$$
\Lambda=\frac{|\mathrm{E}|}{|\mathrm{E}+\mathrm{H}|}=\frac{|\mathrm{E}|}{|\mathrm{T}|}
$$

di mana : $|\mathrm{E}|=$ determinan dari matriks galat (E).

$|\mathrm{T}|=$ determinan dari matriks total $(\mathrm{T})$. 
jika $\Lambda>U_{p}, v_{H}, v_{E}$, maka terima $H_{0}$

jika $\Lambda<U_{p}, v_{H}, v_{E}$, maka tolak $H_{0}$

keterangan :

$\mathrm{p} \quad=$ banyaknya variabel respon.

$v_{H} \quad=$ derajat bebas perlakuan.

$v_{E} \quad=$ derajat bebas total.

Dari besaran Lambda-Wilks dapat dilakukan transformasi ke besaran statistik $\mathrm{F}$, dengan menggunakan tabel distribusi F seperti pada Tabel 2.

Tabel 2 Tranformasi dari $\Lambda$ ke F

\begin{tabular}{|c|c|c|c|}
\hline \multicolumn{2}{|c|}{ Parameter } & \multirow{2}{*}{ Transformasi F } & \multirow{2}{*}{ Derajat bebas } \\
\hline $\mathbf{p}$ & $\mathbf{t}$ & & \\
\hline $\mathrm{p}=1$ & $\mathrm{t} \geq 2$ & $\left(\frac{1-\Lambda}{\Lambda}\right)\left(\frac{\sum n_{l}-t}{t-1}\right)$ & $F_{t-1, \sum n_{l}-t}$ \\
\hline $\mathrm{p}=2$ & $\mathrm{t} \geq 2$ & $\left(\frac{1-\sqrt{\Lambda}}{\sqrt{\Lambda}}\right)\left(\frac{\sum n_{l}-t-1}{t-1}\right)$ & $F_{2(t-1), 2\left(\sum n_{l}-t-1\right)}$ \\
\hline $\mathrm{p} \geq 1$ & $\mathrm{t}=2$ & $\left(\frac{1-\Lambda}{\Lambda}\right)\left(\frac{\sum n_{l}-p-1}{p}\right)$ & $F_{p, \sum n_{l}-p-1}$ \\
\hline $\mathrm{p} \geq 1$ & $\mathrm{t}=3$ & $\left(\frac{1-\sqrt{\Lambda}}{\sqrt{\Lambda}}\right)\left(\frac{\sum n_{l}-p-2}{p}\right.$ & $F_{2 p, 2\left(\sum n_{l}-p-2\right)}$ \\
\hline
\end{tabular}

Keterangan: jika F hitung $>\mathrm{F}$ Tabel dengan $\alpha$ tertentu, maka tolak $H_{0}$ jika F hitung $<\mathrm{F}_{\text {Tabel }}$ dengan $\alpha$ tertentu, maka terima $H_{0}$

Penarikan kesimpulan menggunakan software SPSS versi 14 untuk ONE-WAY MANOVA dapat dilihat dari angka-angka signifikan (sig) hasil pengujian yang didasarkan pada: Pillai's Trace, Wilk's Lambda, Hotelling's Trace, dan Roy's Largest Root. Jika angka signifikan lebih besar atau sama dengan nilai dari $\alpha$ maka kesimpulannya adalah terima $H_{0}$, yang artinya tidak ada perbedaan antar rata-rata perlakuan.

Kriteria keputusan menggunakan angka signifikan adalah sebagai berikut ini. Jika angka signifikan (sig) $>\alpha$, maka terima $H_{0}$ Jika angka signifikan (sig) $<\alpha$, maka tolak $H_{0}$ 
Dalam menentukan nilai-nilai pembanding ortogonal $\left\{c_{i}\right\}$ perlu diusahakan agar berlaku:

$\sum_{i=1}^{t} c_{i} n_{i}=0$

Terdapat banyak cara untuk memilih koefisien dari kontras ortogonal untuk beberapa perlakuan. Sebagai contoh, misalnya terdapat $\mathrm{t}=3$ perlakuan, dengan perlakuan 1 sebagai kontrol dan perlakuan 2 dan 3 adalah faktor yang diuji oleh peneliti, masing-masing perlakuan memiliki ukuran contoh $\left(n_{i}\right)$. Kontras ortogonal yang dapat dibentuk adalah seperti pada contoh Tabel 3 .

Tabel 3 Koefisien Kontras Ortogonal

\begin{tabular}{lccc}
\hline & \multicolumn{3}{c}{ Perlakuan } \\
\cline { 2 - 4 } & Perlakuan-1 & Perlakuan-2 & Perlakuan-3 \\
\hline Ukuran contoh & 2 & 3 & 1 \\
$n_{i}$ & & & -1 \\
\hline Nilai Pembanding $\left(C_{i}\right)$ & -1 & +1 & +3 \\
kontras 1 $\left(H_{1}\right)$ & 0 & -1 & \\
kontras 2 $\left(H_{2}\right)$ & & & \\
\hline
\end{tabular}

Dinyatakan bahwa kontras 1 dengan $c_{1}=-1, c_{2}=+1, c_{3}=-1$ membandingkan Perlakuan-1 terhadap Perlakuan-2 dan Perlakuan-3, dan kontras 2 dengan $c_{1}=0, c_{2}=-1, c_{3}=+3$ membandingkan Perlakuan-2 terhadap Perlakuan-3.

Untuk prosedur pengambilan keputusan dapat digunakan prosedur seperti analisis ragam multivariat. Analisis ragam untuk uji kontras ortogonal dapat dilihat pada Tabel 4.

Tabel 4 Analisis Ragam untuk Uji Kontras Ortogonal

\begin{tabular}{lll}
\hline \multicolumn{1}{c}{ Sumber Keragaman } & \multicolumn{1}{c}{ Matriks JK dan JHKH } & Derajat bebas \\
\hline Perlakuan (H) & $\mathbf{J K}_{\text {Perlakuan }}$ & $\mathrm{t}-1$ \\
Kontras Ortogonal & $\mathbf{J K}_{H 1}$ & 1 \\
$H_{1}$ & $\mathbf{J K}_{H 2}$ & 1 \\
$H_{2}$ & $\ldots$ & 1 \\
$\ldots$ & $\mathbf{J K}_{\text {Galat }}$ & $\sum_{l=1}^{t} n_{l}-t$ \\
Galat (E) & $\mathbf{J K}_{\text {Total }}$ & \\
\hline \multirow{2}{*}{ Total } & & $\sum_{l=1}^{t} n_{l}-1$ \\
\hline
\end{tabular}


Untuk mencari Jumlah Kuadrat Kontras dan Jumlah Hasil Kali dapat dilihat pada persamaan sebagai berikut ini.

$$
\begin{aligned}
& \mathbf{J K}_{H}=\frac{\left(\sum_{i=1}^{t} c_{i} x_{i . k}\right)^{2}}{\sum_{i=1}^{t} n_{i} c_{i}{ }^{2}} \\
& \mathbf{J H K H}=\frac{\left(\sum_{i=1}^{t} c_{i} x_{i . k}\right)\left(\sum_{i=1}^{t} c_{i} x_{i . l}\right)}{\sum_{i=1}^{t} n_{i} c_{i}{ }^{2}} \quad(\mathrm{k} \neq 1 ; \mathrm{k}, \mathrm{l}=1,2, \ldots, \mathrm{p}) \\
& \mathbf{J K}_{\text {Total }}=\mathbf{J K}_{\text {Perlakuan }}+\mathbf{J K}_{\text {Galat }}
\end{aligned}
$$

Jumlah pembanding yang dapat dibuat untuk uji hipotesis pada uji kontras ortogonal adalah t1 atau jumlah perlakuan dikurang satu. Pada contoh seperti Tabel 4, jumlah pembanding kontras ortogonal yang dapat dibentuk ada $(\mathrm{t}-1)=2$ dari $\mathrm{t}=3$ perlakuan, yakni sebagai berikut.

$H_{1}$ : Perlakuan 1 vs (Perlakuan $2+$ Perlakuan 3).

$\mathrm{H}_{2}$ : Perlakuan 2 vs Perlakuan 3.

Uji hipotesis untuk $H_{1}$ :

$H_{0}$ : Rata-rata Perlakuan 1 = rata-rata Perlakuan 2 dan Perlakuan 3.

$H_{1}$ : Rata-rata Perlakuan $1 \neq$ rata-rata Perlakuan 2 dan Perlakuan 3.

Uji hipotesis untuk $H_{2}$ :

$H_{0}$ : Rata-rata Perlakuan 2 = rata-rata Perlakuan 3.

$H_{1}$ : Rata-rata Perlakuan $2 \neq$ rata-rata Perlakuan 3.

Untuk menguji hipotesis yang telah dikemukakan, maka dapat menggunakan uji LambdaWilks ( $\Lambda$-Wilks) menggunakan table distribusi U, sebagai berikut (contoh diambil dari Tabel.4).

Untuk menguji hipotesis $H_{1}$, yakni sebagai berikut.

$$
\Lambda=\frac{|\mathrm{E}|}{\left|\mathrm{E}+H_{1}\right|}
$$

di mana :

$|\mathrm{E}|=$ determinan dari matriks galat $(\mathrm{E})$.

$\left|\mathrm{E}+H_{1}\right|=$ determinan dari matriks $\mathrm{E}+H_{1}$.

Untuk menguji hipotesis $H_{2}$, yaitu:

$$
\Lambda=\frac{|\mathrm{E}|}{\left|\mathrm{E}+H_{2}\right|}
$$

di mana :

$|\mathrm{E}|=$ determinan dari matriks galat $(\mathrm{E})$.

$\left|\mathrm{E}+\mathrm{H}_{2}\right|=$ determinan dari matriks $\mathrm{E}+\mathrm{H}_{2}$. 
Kriteria kesimpulan dari uji hipotesis kontras ortogonal adalah sebagai berikut.

Jika $\Lambda>U_{p}, v_{H}, v_{E}$, maka terima $H_{0}$, sedangkan

Jika $\Lambda<U_{p}, v_{H}, v_{E}$, maka tolak $H_{0}$

keterangan :

$\mathrm{p}$ = banyaknya variabel respon.

$V_{H}=$ derajat bebas perlakuan.

$v_{E}=$ derajat bebas total.

\section{METODE PENELITIAN}

Sampel diambil dari 10 tempat penjualan air minum isi ulang di sekitar kampus Syahdan dan Anggrek Universitas Bina Nusantara pada bulan Mei 2009. Sumber air yang dipilih adalah dari Ciburial Bogor. Terhadap sepuluh sampel dilakukan pengujian kadar $\mathrm{CN}, \mathrm{Pb}, \mathrm{Mn}, \mathrm{Cr}$, dan $\mathrm{Cd}$ di laboratoium PT Buana Tirta Abadi Cikarang sebelum dilakukan filtrsi dan setelah dilakukan filtrasi Granular Activated Charcoal, Reserve Osmosis, dan Hollow Fiber. Data hasil pengujian dianalisis menggunakan One Way Manova.

Uji lanjut yang digunakan adalah uji kontras ortogonal. Secara spesifik uji kontras ortogonal membandingkan hal sebagai berikut ini. Pertama, perlakuan rata-rata kontrol terhadap rata-rata ketiga proses air minum (proses filter Reserve Osmosis, proses filter Granular Activated Charcoal, proses filter hollow fiber). Kedua, perlakuan rata-rata proses filter Reserve Osmosis dengan proses filter hollow fiber. Ketiga, perlakuan rata-rata proses filter Reserve Osmosis dengan proses filter Granular Activated Charcoal.

\section{HASIL DAN PEMBAHASAN}

Hasil pengukuan rata-rata kandungan $\mathrm{CN}, \mathrm{Pb}, \mathrm{Mn}, \mathrm{Cr}$, dan $\mathrm{Cd}$ dalam sampel yang tidak diproses filtrasi dibanding dengan proses filtrasi Reserve Osmosis (RO), Granular Activated Chacoal (GAC) dan Hollow Fiber (HF) dapat dilihat pada Tabel 5.

Tabel 5 Rata-rata Kandungan Zat Kimia Anorganik pada Sampel Kontrol dan Tiga Proses Filterisasi

\begin{tabular}{ccccc}
\hline $\begin{array}{c}\text { Zat Kimia } \\
\text { Anorganik }\end{array}$ & $\begin{array}{c}\text { Sampel } \\
\text { Kontrol } \\
(\mathbf{m g} / \mathbf{L})\end{array}$ & $\begin{array}{c}\text { Filter RO } \\
\text { (mg/L) }\end{array}$ & $\begin{array}{c}\text { Filter GAC } \\
\text { (mg/L) }\end{array}$ & $\begin{array}{c}\text { Filter hollow } \\
\text { fiber (mg/L) }\end{array}$ \\
\hline Sianida & 0.0431 & 0.0017 & 0.0035 & 0.0017 \\
Timbal & 0.5700 & 0.0310 & 0.0480 & 0.0410 \\
Mangan & 0.1230 & 0.0024 & 0.0122 & 0.0037 \\
Kromium & 0.5700 & 0.0150 & 0.0320 & 0.0410 \\
Kadmium & 0.0332 & 0.0025 & 0.0026 & 0.0027 \\
\hline
\end{tabular}


Pada Tabel 5 dapat dilihat bahwa air minum yang diproses dengan menggunakan proses filter Reserve Osmosis (RO) menghasilkan air minum dengan kandungan ke lima zat kimia anorganik yang lebih sedikit dari pada proses filterisasi yang lain.

Hasil pengujian varian-kovarian menggunakan Box's M test berbantukan software SPSS versi 14 dapat dilihat pada Gambar 4.

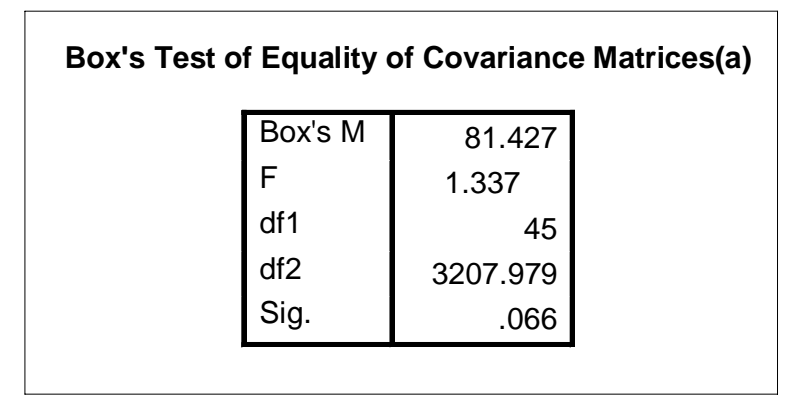

Gambar 4 Hasil Pengujian Varian-kovarian (Box’M test) Menggunakan SPSS

Kesimpulan dari Gambar 4 adalah nilai signifikan (sig) bernilai 0.066 dengan alpha sama dengan 0.01 . Karena $0.066>0.01$ maka varian-kovarian pada variabel tak bebas adalah sama pada semua perlakuan. Gambar 5.

Hasil analisis ragam multivariat satu arah menggunakan software SPSS dapat dilihat pada

\section{Multivariate Tests(c)}

\begin{tabular}{rlrrrrc}
\hline Effect & & Value & \multicolumn{1}{c}{ F } & Hypothesis df & Error df & Sig. \\
\hline perlakuan & Pillai's Trace & 1.706 & 8.969 & 15.000 & 102.000 & .000 \\
& Wilks' Lambda & .014 & 22.145 & 15.000 & 88.739 & .000 \\
& Hotelling's Trace & 23.727 & 48.509 & 15.000 & 92.000 & .000 \\
& Roy's Largest Root & 21.676 & $147.399(\mathrm{~b})$ & 5.000 & 34.000 & .000 \\
\hline
\end{tabular}

Gambar 5 Hasil Perhitungan ONE-WAY MANOVA Menggunakan MINITAB

Pada Gambar 5, Angka signifikan hasil pengujian pada keempat test (Pillai's Trace, Wilk's Lambda, Hotelling's Trace, dan Roy's Largest Root), yaitu 0.000, dengan nilai alpha sama dengan 0.01. Karena semua angka signifikan kurang dari nilai alpha $(0.000<0.01)$ maka kesimpulannya $H_{0}$ ditolak dan berarti ada perbedaan rata-rata pada keempat perlakuan.

Karena dari hasil analisis ragam ternyata menyimpulkan adanya perbedaan rata-rata tiap perlakuan, maka untuk tahap selanjutnya dilakukan uji lanjut dengan analisis ragam untuk mencari perlakuan atau proses mana yang berbeda. Hasil analisis ragam untuk uji Kontras Ortogonal tertera pada Tabel 6. 
Tabel 6 Analisis Ragam untuk Uji Kontras Ortogonal

\begin{tabular}{llc}
\hline \multicolumn{1}{c}{ Sumber Keragaman } & $\begin{array}{c}\text { Matriks JK dan } \\
\text { JHKH }\end{array}$ & Derajat bebas \\
\hline Perlakuan (H) & $\mathbf{J K}_{\text {Perlakuan }}$ & 3 \\
Kontras Ortogonal & $\mathbf{J K}_{H 1}$ & 1 \\
$H_{1}$ & $\mathbf{J K}_{H 2}$ & 1 \\
$H_{2}$ & $\mathbf{J K}_{H 3}$ & 1 \\
$H_{3}$ & $\mathbf{J K}_{\text {Galat }}$ & 36 \\
Galat (E) & $\mathbf{J K}_{\text {Total }}$ & \\
\hline Total & & 39 \\
\hline
\end{tabular}

Pengujian hipotesis untuk $H_{1}, H_{2}$, dan $H_{3}$, yaitu sebagai berikut.

$H_{1}=$ rata-rata proses kontrol tidak sama dengan rata-rata proses filter GAC, proses filter RO, proses filter hollow fiber.

$$
\Lambda=\frac{|E|}{\left|E+H_{1}\right|}=\frac{1.07744 \mathrm{E}-18}{1.17131 \mathrm{E}-17}=0.091985
$$

Dari hasil $\Lambda=0.091985$ dibandingkan dengan tabel distribusi $U$ pada taraf nyata $\alpha=0.01$, dengan $\mathrm{p}=5, v_{H 1}=1, v_{E}=36$, maka $U_{5 ; 1 ; 36}^{0.01}=0.744010$. Karena $\Lambda=0.091985$ lebih kecil dari $U_{5 ; 1 ; 36}^{0.01}=0.744010$, maka keputusannya adalah tolak $H_{0}$. Atau terima $H_{1}$ $H_{1}=$ rata-rata proses filter RO tidak sama dengan rata-rata proses filter hollow fiber.

$$
\Lambda=\frac{|E|}{\left|E+H_{2}\right|}=\frac{1.07744 \mathrm{E}-18}{2.78808 \mathrm{E}-18}=0.386444
$$

Dari hasil $\Lambda=0.386444$ dibandingkan dengan tabel distribusi $\mathrm{U}$ pada taraf nyata $\alpha=0.01$, dengan $\mathrm{p}=5, v_{H 2}=1, v_{E}=36$, maka $U_{5 ; 1 ; 36}^{0.01}=0.744010$. Karena $\Lambda=0.386444$ lebih kecil dari $U_{5 ; 1 ; 36}^{0.01}=0.744010$, maka keputusannya adalah tolak $H_{0}$.

$H_{1}=$ rata-rata proses filter RO tidak sama dengan rata-rata proses filter GAC.

$$
\Lambda=\frac{|E|}{\left|E+H_{3}\right|}=\frac{1.07744 \mathrm{E}-18}{9.62844 \mathrm{E}-18}=0.111901
$$

Dari hasil $\Lambda=0.111901$ dibandingkan dengan tabel distribusi $\mathrm{U}$ pada taraf nyata $\alpha=0.01$, dengan $\mathrm{p}=5, v_{H 2}=1, \quad v_{E}=36$, maka $U_{5 ; 1 ; 36}^{0.01}=0.744010$. Karena $\Lambda=0.111901$ lebih kecil dari $U_{5 ; 1 ; 36}^{0.01}=0.744010$, maka keputusannya adalah tolak $H_{0}$. 


\section{SIMPULAN}

Dari hasil analisis manova menunjukan bahwa air yang tidak melalui proses filtrasi memiliki kandungan zat kimia anorganik (CN,Pb.Mn.Cr dan $\mathrm{Cd}$ ) lebih tinggi dibanding dengan air yang melalui proses filtrasi. Proses filtrasi Riserve Osmosis (RO) merupakan filtrasi yang menghasilkan air dengan kandungan zat kimia anorganik terendah dibanding dengan filtrasi Hollow Fiber (HO) dan Granula Activated Charcoal (GAC). Perbedaan rata-rata kandungan zat kimia anorganik dari ketiga proses filtrasi cukup signifikan pada taraf $\alpha=0,01$.

\section{DAFTAR PUSTAKA}

Brown, A. L. (1994). Freshwater ecology, London: Heinenmann Educational Books.

Eckenfelder, W. W. (2002). Industrial water pollution control, $2^{\text {nd }}$ ed., New York: McGraw-Hill, Inc.

Hair, J. F. (2002). Multivariate data analysis, $5^{\text {th }}$ ed., New Jersey: Prentice Hall.

Johnson, R. A., and Wichern, D. W. (2002). Applied multivariate statistical analysis, $5^{\text {th }}$ ed., Engelwood Cliffs, New Jersey: Prentice Hall.

Kowal. J. A. (1992). Behavior models: Specifying user's expectations, New Jersey: Prentice Hall.

Montgomery, D. C. (2005). Design and analysis of experiments, $6^{\text {th }}$ ed., Arizona: John Wiley and Sons.

Ott, L. (1984). An introduction to statistical methods and data Analysis, $2^{\text {nd }}$ ed., Duxbury Press.

Schildt, H. (2005). Java: The complete references, J2SE, $5^{\text {th }}$ ed., New York: Osborne / McGraw Hill.

SPSS versi 14. Diakses April 2009 dari Http://www.spss.com.

Supranto, J. (2004). Analisis multivariat: Arti dan interpretasi, Rineka Cipta. 